\title{
Problematika Pembelajaran Sejarah Sastra di Kampus Wilayah Perbatasan Negara Kesatuan Republik Indonesia- Republik Demokratik Timor Leste
}

\author{
The Problematics Learning of the History of Literature at Campus in the Border of \\ Indonesia-Timor Leste
}

\author{
Uman Rejo \\ Universitas Timor \\ Corresponding email: umanrejo@unimor.ac.id
}

Received: 29 October 2020 Accepted: 11 April 2021 Published: 4 August 2021

\begin{abstract}
This research aims to explore and describe some of the problems experienced in the learning History of Literature courses in Indonesian Language and Literature Education courses on the campus of the border region of the Unitary State of the Republic of Indonesia-Democratic Republic of Timor Leste (NKRI-RDTL). One of the campuses located in the border area is the University of Timor (Unimor). The problems explored will be balanced with several solutions and recommendations, to reduce some of the problems represented. In this case, the method used is a qualitative descriptive method using an e-ethical paradigm. This paradigm was used by Clifford Geertz in The Religion of Java which was presented to Abangan Santri dan Priyayi dalam Masyarakat Jawa (1981) by Aswab Mahasin. About Timorese culture, Gregor Neonbasu applied this paradigm in his monograph entitled Citra Manusia Berbudaya: Sebuah Monografi tentang Timor dalam Perspektif Melanesia (2017). The subject of this research is the study activity learning History of Literature inactive students of the first semester (odd) study program of Indonesian Language and Literature Education Faculty of Educational Sciences, University of Timor academic year 2019-2020. Based on the results of the study concluded that the problem faced in the learning History of Literature courses on the campus of the border area of NKRI-RDTL is due to five aspects, namely material aspects or teaching materials, methods, media, students, and literacy.
\end{abstract}

Keywords: problematic, learning, History of Literature, border area, emic-ethical paradigm

Abstrak: Penelitian ini bertujuan untuk mengeksplorasi dan mendeskripsikan beberapa problematika yang dialami dalam pembelajaran mata kuliah Sejarah Sastra pada program studi Pendidikan Bahasa dan Sastra Indonesia di kampus wilayah perbatasan Negara Kesatuan Republik Indonesia-Republik Demokratik Timor Leste (NKRI-RDTL). Salah satu kampus yang berada di wilayah perbatasan tersebut adalah Universitas Timor (Unimor). Problematika yang dieksplorasi tersebut akan diimbangi dengan beberapa solusi dan rekomendasi, sehingga dapat mengurangi beberapa problematika yang direpresentasikan. Dalam hal ini, metode yang digunakan adalah metode deskriptif kualitatif dengan menggunakan paradigma emik-etik. Paradigma ini pernah digunakan Clifford Geertz dalam The Religion of Java yang dialihbahasakan menjadi Abangan Santri dan Priyayi dalam Masyarakat Jawa (1981) oleh Aswab Mahasin. Dalam kaitannya dengan budaya Timor, Gregor Neonbasu menerapkan paradigma ini dalam monografinya berjudul Citra Manusia Berbudaya: Sebuah Monografi tentang Timor dalam Perspektif Melanesia (2017). Subjek penelitian ini adalah aktivitas pembelajaran Sejarah Sastra pada mahasiswa aktif semester satu (ganjil) program studi Pendidikan Bahasa dan Sastra Indonesia Fakultas Ilmu Pendidikan Universitas Timor tahun akademik 2019-2020. Berdasarkan hasil penelitian disimpulkan bahwa problematika yang dihadapi dalam pembelajaran mata kuliah Sejarah Sastra di kampus wilayah perbatasan NKRI-RDTL ini disebabkan lima aspek, yakni aspek materi atau bahan yang diajarkan, metode, media, mahasiswa, dan literasi.

Kata kunci: problematika, pembelajaran, Sejarah Sastra, wilayah perbatasan, paradigma emik-etik

To cite this article:

Rejo, U. (2021). Problematika Pembelajaran Sejarah Sastra di Kampus Wilayah Perbatasan Negara Kesatuan Republik Indonesia-Republik Demokratik Timor Leste. Diglosia: Jurnal Kajian Bahasa, Sastra, dan Pengajarannya, 4(3), 351-364. https://doi.org/10.30872/diglosia.v4i3.133 


\section{A. PENDAHULUAN}

Pembelajaran di perguruan tinggi tidak bisa disamakan dengan di Sekolah Dasar (SD), Sekolah Menengah Pertama (SMP), Sekolah Menengah Atas (SMA), bahkan Sekolah Menengah Kejuruan (SMK). Masing-masing satuan memiliki karakteristik berbeda satu sama lain. Karakteristik tersebut yang menjadikan pembelajaran semakin berwarna, penuh romantika, serta memiliki panorama yang luas dan bervariatif. Dengan demikian, masing-masing konsep pembelajaran yang diterapkan antara satuan pendidikan tersebut harus diperlakukan berbeda sesuai dengan karakteristiknya. Tidak hanya konsep pembelajaran saja yang berbeda, melainkan pendekatan yang digunakan, metode, media, bahkan sumber belajar yang digunakan harus kontekstual dengan kondisi sosial-budaya dan geografis setiap wilayah yang dijadikan tempat satuan pendidikan tersebut. Sehingga misi atau target utama pembelajaran dapat tercapai secara maksimal dan optimal.

NKRI-RDTL merupakan singkatan Negara Kesatuan Republik IndonesiaRepublik Demokratik Timor Leste. Menurut Riana (2016), secara geografis RDTL berada di Asia Tenggara tepatnya berada di Barat Laut Australia di Kepulauan Sunda Lesser, pada ujung timur NKRI. Jadi, kawasannya meliputi separuh bagian timur dari Pulau Timor, serta daerah Oecussi (Ambeno) di bagian timur laut Pulau Timor. Secara historis, RDTL semula dijajah bangsa Portugis, NKRI dijajah bangsa Belanda selama 3,5 abad, dan Inggris menguasai Singapura. Kedatangan bangsa Eropa ke Asia Tenggara semula berdagang dan mencari rempah-rempah. Karena suburnya negara ini serta mudah dapat dikuasai, maka mereka mulai menjajahnya. RDTL merdeka dijajah Portugis pada 28 November 1975, namun secara resmi baru merdeka secara penuh pada 20 Mei 2012. Sebelum merdeka secara penuh, RDTL dikuasai NKRI, dijadikan sebagai provinsi ke-33 NKRI, dan berakhir setelah masa pemerintahan Presiden B.J. Habibie. Setelah itu, secara resmi masuk menjadi anggota $\mathrm{PBB}$ dan berganti nama menjadi negara RDTL.

Sebagai wilayah perbatasan, banyak sekali problematika yang dihadapi dan ditemukan. Dalam paper berjudul Kebijakan Pengelolaan Kawasan Perbatasan Indonesia (2011), dikatakan hampir semua kawasan perbatasan Indonesia adalah daerah tertinggal yang kondisinya sangat memprihatinkan sebagai wajah luar negara. Selama ini kawasan tersebut dikelola dengan mengedepankan pendekatan keamanan (safety belt approach), sehingga pembangunan sosial, budaya, pendidikan, dan ekonomi menjadi terabaikan. Penguatan modal sosial, ekonomi, dan budaya masyarakat di kawasan tersebut (termasuk peningkatan kualitas dan kuantitas sarana prasarana) harus disertai dengan peningkatan SDM. Ada lima kawasan yang berada di wilayah perbatasan, yakni provinsi Kalimantan Timur, Kalimantan Barat, Kepulauan Riau, Papua, dan Nusa Tenggara Timur.

Dalam paper tersebut dikatakan pula bahwa di provinsi Nusa Tenggara Timur kondisi kawasan perbatasannya belum menunjukkan gambaran yang ideal berada di kabupaten Belu, kabupaten Timor Tengah Utara, dan kabupaten Kupang. Ada lima permasalahan mendasar yang dihadapi oleh masyarakat di kawasan perbatasan NTT. Pertama, rendahnya tingkat kesejahteraan masyarakat di kawasan perbatasan. Hal ini diperparah dengan tiadanya ketrampilan dalam mengelola sumber daya lahan yang kering serta terbatasnya sarana permodalan untuk membangun investasi di bidang perkebunan, rendahnya derajat kesehatan masyarakat yang ditandai dengan tingginya angka kematian bayi dan ibu yang melahirkan, kasus gizi buruk, meningkatkan HIV/AIDS, tidak tersedianya pemukiman yang sehat, dan persediaan 
air bersih yang tidak memadai. Kedua, tidak memadainya sarana dan prasarana pendidikan, kesehatan, perhubungan, penerangan, sehingga menyebabkan penduduk di kawasan ini menjadi terisolir. Ketiga, kerusakan lingkungan hidup sebagai akibat dari beralihnya fungsi hutan menjadi lahan pertanian. Pengambilan galian tambang, marmer, dan galian $\mathrm{C}$ yang tidak memperhatikan kelestarian lingkungan, serta rendahnya kepedulian masyarakat dalam mengelola daerah aliran sungai di perbatasan. Keempat, ketertiban dan keamanan di kawasan perbatasan masih menunjukkan dinamika yang tinggi. Kelima, pemecahan masalah di kawasan perbatasan NTT terkesan belum efektif.

Universitas Timor atau Unimor merupakan salah satu perguruan tinggi negeri yang berada di provinsi Nusa Tenggara Timur (NTT), khususnya berada di wilayah perbatasan NKRI-RDTL. Sebelum menjadi perguruan tinggi negeri, kampus ini merupakan perguruan tinggi swasta dengan nama Universitas Timor Timur (Untim) yang didirikan kali pertama oleh Yayasan Pendidikan Cendana Wangi berdasarkan Keputusan Menteri Pendidikan Nasional Republik Indonesia pada 6 Juni 2000 nomor 67/D/O/2000 dan berada di dalam naungan Koordinasi Perguruan Tinggi Swasta Wilayah VIII (Kopertis VIII). Baru pada tanggal 6 Oktober 2014 kampus ini ditetapkan sebagai perguruan tinggi negeri berdasarkan Peraturan Presiden Republik Indonesia nomor 119 tahun 2014. Sampai tulisan ini selesai ditulis, kampus ini masih memiliki empat fakultas, yakni Fakultas Ilmu Pendidikan (FIP), Fakultas Ilmu Sosial dan Ilmu Politik (FISIP), Fakultas Ekonomi dan Bisnis (FEB), dan Fakultas Pertanian (Faperta). Tiap-tiap fakultas tersebut memiliki beberapa program studi. Salah satu program studinya adalah program studi Pendidikan Bahasa dan Sastra Indonesia yang berada di dalam naungan Fakultas Ilmu Pendidikan (FIP).

Program studi Pendidikan Bahasa dan Sastra Indonesia merupakan salah satu program studi yang sudah ada sejak kampus ini masih berstatus swasta. Jadi, dapat dikatakan sebagai program studi yang usianya di atas dua puluh tahunan. Ditinjau dari kurikulum yang membentuk program studi ini, ada tiga rumpun mata kuliah yang ikut menyusunnya yakni rumpun mata kuliah pendidikan, bahasa atau linguistik, dan susastra. Misalnya saja, untuk rumpun mata kuliah susastra di program studi ini terdapat mata kuliah Sejarah Sastra, Teori Sastra, Apresiasi Prosa Fiksi dan Drama, Apresiasi Puisi, Folklor, Kritik Sastra, Sanggar Sastra, dan Teknik Penyutradaraan. Masing-masing mata kuliah memiliki deskripsi dan capaian pembelajaran mata kuliah (CPMK) yang berbeda satu sama lain yang ikut menunjang kompetensi yang diberikan untuk mahasiswa.

Mata kuliah Sejarah Sastra merupakan salah satu mata kuliah rumpun susastra yang diberikan pada program studi Pendidikan Bahasa dan Sastra Indonesia. Melalui mata kuliah ini, mahasiswa diharapkan dapat memahami perkembangan sastra Indonesia dari awal terbentuk sampai sekarang serta diharapkan pula mahasiswa dapat memahami konsep dasar dan problema yang dihadapi dalam penyusunan sejarah sastra Indonesia. Di kampus ini, mata kuliah Sejarah Sastra diberikan pada semester satu dengan bobot 3 SKS. Mata kuliah ini merupakan mata kuliah yang wajib diprogram dan termasuk mata kuliah syarat. Artinya, jika mahasiswa tidak memprogram mata kuliah ini maka tidak bisa memprogram mata kuliah rumpun susastra yang lain.

Pada prinsipnya, pembelajaran yang diterapkan di perguruan tinggi lebih menggunakan konsep pembelajaran andragogi atau pembelajaran orang dewasa. Hal ini yang membedakan dengan pembelajaran pada satuan pendidikan lainnya. 
Menurut Wahono dkk. (2020), ada lima prinsip pembelajaran andragogi yang berhasil disimpulkannya. Pertama, pembelajaran orang dewasa sangat berbeda dengan pembelajaran anak-anak. Kaidah pembelajaran yang sering digunakan dalam pembelajaran ini adalah perbincangan kumpulan, penyelesaian masalah, dan bertukar pengalaman berbasis teknologi informasi. Kedua, orang dewasa belajar dengan lebih baik apabila mereka terlibat secara aktif dalam proses merancang, menilai dan melaksanakan proses pembelajaran yang mereka ikuti. Ketiga, orang dewasa belajar dengan lebih berkesan apabila topik itu bernilai, serta mampu membantu permasalahan yang dihadapi dalam kehidupan dan pekerjaan mereka sehari-hari. Keempat, orang dewasa belajar dengan baik apabila mereka mempunyai motivasi untuk berubah, self-discovered atau mempunyai ketrampilan dan strategi spesifik berbasis daring. Kelima, salah satu kendala dalam pembelajaran orang dewasa adalah bahwasannya orang dewasa pada umumnya telah memiliki pengetahuan dan sikap sehingga sulit menerima perubahan.

Dalam implementasinya, prinsip pembelajaran orang dewasa atau yang lebih dikenal dengan nama pembelajaran andragogi ini apabila diterapkan secara penuh untuk mahasiswa yang berada di wilayah perbatasan masih dapat dikatakan belum maksimal dan optimal. Apalagi diterapkan untuk pembelajaran Sejarah Sastra di program studi Pendidikan Bahasa dan Sastra Indonesia yang berada di kawasan perbatasan ini, masih banyak problematika yang akan ditemukan dan dihadapi. Oleh karena itu, berbagai strategi, solusi, dan rekomendasi dikaji lebih intensif, untuk direlevansikan dengan kondisi sosial-budaya dan geografis mahasiswa yang berada di kawasan perbatasan. Dengan harapan, agar target pembelajaran yang telah ditetapkan pada setiap mata kuliah dapat tercapai secara optimal dan maksimal sehingga kompetensi-kompetensi bidang yang ditargetkan program studi dalam hal ini dapat terpenuhi dan tepat sasaran.

Misi utama penelitian ini dilakukan adalah untuk mengeksplorasi dan mendeskripsikan beberapa problematika yang dialami dalam pembelajaran mata kuliah Sejarah Sastra pada program studi Pendidikan Bahasa dan Sastra Indonesia di kampus wilayah perbatasan NKRI-RDTL. Salah satu kampus yang berada di wilayah perbatasan tersebut adalah Universitas Timor. Problematika yang dieksplorasi tersebut akan diimbangi dengan beberapa solusi dan rekomendasi, sehingga dapat mengurangi beberapa problematika yang direpresentasikan. Selain itu, mahasiswa dapat menikmati berbagai varian rasa nuansa pembelajaran Sejarah Sastra setelah mendapat evaluasi semacam ini. Varian rasa itu akan dinikmati oleh mahasiswa pada semester berikutnya yang akan memprogram mata kuliah Sejarah Sastra ini. Oleh karena itu, evaluasi semacam ini akan menjadi tradisi rutinan untuk semakin memperkuat pembelajaran bidang susastra di kampus Universitas Timor program studi Pendidikan Bahasa dan Sastra Indonesia yang berada di kawasan perbatasan ini. Hal tersebut yang menjadi target utama untuk perkembangan mata kuliah bidang susastra berikutnya.

Untuk melakukan eksplorasi dan mendeskripsikan beberapa problematika dalam pembelajaran Sejarah Sastra, maka peneliti menggunakan paradigma etikemik. Paradigma ini pernah digunakan Clifford Geertz dalam buku The Religion of Java yang selanjutnya dialihbahasakan menjadi buku Abangan Santri dan Priyayi dalam Masyarakat Jawa (1981) oleh Aswab Mahasin. Dalam kaitannya dengan budaya Timor, Gregor Neonbasu menerapkan paradigma ini dalam buku monografinya berjudul Citra Manusia Berbudaya: Sebuah Monografi tentang Timor 
dalam Perspektif Melanesia (2017). Dengan demikian, melalui pengalaman beberapa pakar tersebut peneliti menggunakan paradigma etik-emik ini untuk mengeksplorasi dan mendeskripsikan target utama yang telah difokuskan dalam penelitian ini. Dengan harapan, hasil dan bahasan yang dihasilkan dapat menjadi runtut, jelas, fokus, terarah, dan menjadi semakin komprehensif. Selain itu, hasil dan bahasannya dapat memberi kontribusi pada pengembangan pembelajaran Sejarah Sastra di kampus ini. Tidak hanya disajikan untuk yang berada di kawasan perbatasan saja, melainkan dapat dijadikan semacam barometer evaluasi pembelajaran mata kuliah di kawasan yang berada di luar wilayah perbatasan.

\section{B. METODE}

Penelitian ini menggunakan metode deskriptif kualitatif. Metode ini efektif dan efisien digunakan karena mampu memberikan pemahaman dan penjelasan yang memadai sehubungan dengan fakta-fakta empirik yang berkaitan dengan problematika pembelajaran Sejarah Sastra yang dibahas. Secara umum, sumber data yang digunakan dalam tulisan ini dapat dibedakan menjadi dua, yakni sumber data primer dan sekunder. Sumber data primer berupa aktivitas pembelajaran Sejarah Sastra pada mahasiswa aktif semester satu (ganjil) program studi Pendidikan Bahasa dan Sastra Indonesia Fakultas Ilmu Pendidikan Universitas Timor tahun akademik 2019-2020. Selanjutnya, sumber data sekunder berupa data-data yang menunjang fokus utama dalam bahasan tulisan ini. Data-data penunjang tersebut berupa bukubuku yang membahas tentang beberapa problematika yang dihadapi dalam pembelajaran sastra, laporan hasil penelitian yang berkaitan dengan topik yang dibahas, serta artikel-artikel ilmiah baik berbentuk artikel jurnal ataupun artikel yang terpublikasikan di berbagai media. Oleh karena metode yang digunakan deskriptif kualitatif, maka data yang digunakan berbentuk kata-kata dan kalimat yang terdapat dalam sumber data.

Teknik pengumpulan data yang digunakan adalah teknik wawancara atau interview, teknik pustaka, teknik observasi, dan teknik catat. Teknik wawancara ini digunakan untuk mendapatkan informasi dari narasumber secara lengkap. Kegiatan wawancara ini akan dilakukan secara informal, yakni dilakukan dalam keadaan santai, pertanyaan dan jawabannya berjalan seperti tanya jawab biasa dalam kehidupan sehari-hari. Narasumber dalam penelitian ini adalah mahasiswa aktif semester satu (ganjil) program studi Pendidikan Bahasa dan Sastra Indonesia Fakultas Ilmu Pendidikan Universitas Timor tahun akademik 2019-2020 yang memprogram mata kuliah Sejarah Sastra dengan peneliti sebagai pengampunya. Teknik pustaka merupakan salah satu teknik pengumpulan data dan informasi yang dilakukan dengan menelaah sumber-sumber tertulis. Sumber-sumber tertulis tersebut seperti yang telah disampaikan pada bagian sebelumnya, tepatnya pada bagian sumber data. Teknik observasi atau pengamatan dalam hal ini menggunakan cara langsung, yakni dengan mengamati seluruh aktivitas pembelajaran dalam kelas. Dalam hal ini, kelas yang digunakan adalah kelas yang peneliti gunakan dalam mengampu mata kuliah Sejarah Sastra di program studi ini. Setelah menggunakan teknik-teknik tersebut, maka teknik selanjutnya yang digunakan adalah teknik catat. Teknik catat merupakan teknik pengumpulan data yang dilakukan dengan cara mencatat semua data yang telah digunakan saat pengumpulan data menggunakan teknik pustaka. 
Untuk analisis data, teknik yang digunakan adalah teknik analisis isi atau content analysis. Teknik analisis ini sangat sesuai digunakan karena memberikan pemahaman dan penjelasan terhadap isi yang dianalisis. Cara menggunakan teknik ini dengan menguraikan problematika yang dihadapi dalam pembelajaran mata kuliah Sejarah Sastra pada program studi Pendidikan Bahasa dan Sastra Indonesia di kampus wilayah perbatasan NKRI-RDTL secara objektif, sistematik, detil, dan mendalam sesuai dengan fokus bahasan dalam tulisan ini. Hal ini dilakukan dengan tujuan utama agar problematika yang ditekankan dapat tersampaikan secara optimal, sehingga hasilnya dapat diklasifikasikan berdasarkan aspek-aspek yang telah ditentukan dan solusi bisa disimpulkan secara maksimal dengan diikuti rekomendasi yang saling berkaitan. Setelah menggunakan teknik analisis isi, maka langkah selanjutnya adalah menyampaikan hasil dan bahasannya dalam bentuk artikel jurnal, yang kemudian dipublikasikan dalam jurnal ilmiah dengan mengikuti gaya selingkung yang disediakan oleh tim redaksi melalui lamannya.

\section{PEMBAHASAN}

\section{Problematika dari Aspek Materi atau Bahan yang Diajarkan}

Ditinjau dari aspek materi yang digunakan dalam perkuliahan, terdapat problematika yang dihadapi dalam pembelajaran mata kuliah Sejarah Sastra yang dihadapi oleh mahasiswa. Kecenderungan mahasiswa aktif yang memprogram mata kuliah ini saat Sekolah Menengah Atas (SMA) berasal dari program Matematika dan Ilmu Pengetahuan Alam (MIPA) dan Ilmu Pengetahuan Sosial (IPS), bahkan ada yang berasal dari Sekolah Menengah Kejuruan (SMK) dari berbagai macam program kejuruannya. Sehingga, materi yang didapat dari mata kuliah ini menjadi asing dan terasa belum banyak yang mengenal dan memahaminya. Hal ini menjadi berbeda saat ada mahasiswa yang ketika SMA mengambil program Ilmu Bahasa dan Budaya (IBB) pasti pernah memperoleh gambaran awal tentang periodisasi dan perkembangan sejarah sastra Indonesia.

Sebagai mata kuliah wajib yang diberikan pada semester satu, sudah seharusnya apabila dosen pengampu mata kuliah menyiapkan bahan ajar untuk mata kuliah ini. Hal ini bertujuan agar membantu mahasiswa dalam memahami perkembangan sejarah sastra Indonesia dengan baik dan benar, sehingga capaian pembelajaran mata kuliah (CPMK) yang ditetapkan dapat tercapai secara maksimal dan optimal. Meskipun terdapat referensi perkuliahan utama yang telah disampaikan dalam awal perkuliahan atau kontrak perkuliahan, keberadaan bahan ajar masih tetap dibutuhkan. Bahan ajar ini bersifat sebagai pengantar dalam memahami setiap materi pokok dalam perkuliahan. Meskipun ada beberapa referensi yang telah diterbitkan secara nasional, baik yang tercetak atau yang telah terdigitalkan.

Bahan ajar yang dibutuhkan mahasiswa dalam hal ini dapat berupa diktat, modul, paper/makalah, handout perkuliahan, atau bahan presentasi dosen yang berupa silinda atau power point. Bahan ajar tersebut berisi ringkasan materi, kutipankutipan intertekstual yang membentuk pengetahuan konstruktif, bahkan garis besar materi yang akan disampaikan dalam perkuliahan tiap pertemuannya. Bahan ajar tersebut minimal memuat beberapa hal, di antaranya Rencana Pembelajaran Semester (RPS) mata kuliah, tugas terstruktur yang harus dipenuhi mahasiswa, kontrak perkuliahan yang telah ditentukan, materi tiap pertemuan, tujuan perkuliahan, uraian materi yang ditampilkan secara deskriptif, dan tugas tiap pertemuan sebagai uji pemahaman yang diberikan pada mahasiswa. Sistematika bisa 
bervariasi, bergantung distinction pengampu mata kuliah, tetapi substansi bahan ajar yang diberikan ke mahasiswa minimal memuat beberapa hal yang telah disampaikan tersebut.

Setelah memiliki bahan ajar sebagai pengantar dalam memahami perkembangan sejarah sastra Indonesia yang disusun pengampu mata kuliah sesuai dengan RPS yang telah disusun, maka mahasiswa diharuskan membaca beberapa referensi wajib yang telah disampaikan. Minimal mahasiswa telah membaca salah satu referensi tersebut. Meskipun untuk mendapatkan referensi tersebut harus membutuhkan perjuangan keras dan ekstra, mulai dari harga sampai bisa membelinya, kecuali yang telah didigitalkan. Referensi wajib tersebut ada yang berbentuk pdf digital, ada yang telah didistribusikan secara umum, bahkan ada yang diterbitkan tetapi jumlah terbatas atau sudah tidak cetak lagi. Menurut Rejo (2020), beberapa referensi wajib tersebut dapat diklasifikasikan menjadi empat kategori, yakni referensi yang tidak cetak lagi, referensi termutakir yang diterbitkan dan dijual secara umum, referensi laporan hasil penelitian, serta referensi dalam bentuk pdf digital. Referensi tersebut telah disampaikan dalam kontrak atau gambaran umum perkuliahan dan diberikan pada mahasiswa.

Menurut Rejo (2020), yang termasuk referensi yang kemungkinan tidak cetak lagi adalah Perdebatan Sastra Kontekstual (1985) oleh Ariel Heryanto yang diterbitkan Rajawali di Jakarta, Novel Populer Indonesia (1982) oleh Jakob Sumardjo yang diterbitkan Nur Cahaya di Yogyakarta, Lintasan Sastra Indonesia Modern 1 (1992) oleh Jakob Sumardjo yang diterbitkan Citra Aditya Bakti di Bandung, Perkembangan Teater dan Drama Indonesia (1997) oleh Jakob Sumardjo yang diterbitkan STSI Press di Bandung, dan Telaah Kritik Sastra Indonesia (1986) oleh Yudiono K.S. yang diterbitkan Angkasa di Bandung. Yang termasuk referensi yang mutakhir dan didistribusikan secara umum adalah Peta Sejarah Sastra Indonesia (2006) oleh Yudiono K.S. yang diterbitkan Fasindo di Semarang, Pengantar Sejarah Sastra Indonesia (2010) oleh Yudiono K.S. yang diterbitkan Grasindo di Jakarta, Pengantar Sejarah Sastra Indonesia Jilid I (2013) oleh Heny Subandiyah yang diterbitkan Pustaka Ilalang di Lamongan, Ikhtisar Sejarah Sastra Indonesia (2013) oleh Ajip Rosidi yang diterbitkan Pustaka Jaya di Bandung, Sejarah Sastra Indonesia Modern (2004) oleh Sarwadi yang diterbitkan Gama Media di Yogyakarta, Kritik Sastra Indonesia Modern (2002) oleh Rachmat Djoko Pradopo yang diterbitkan Gama Media di Yogyakarta, Sejarah Sastra Indonesia (2011) oleh Rosida Rowati dan Ahmad Bahtiar yang diterbitkan Lembaga Penerbitan UIN Syarif Hidayatulloh di Jakarta, Sejarah Perkembangan Sastra Indonesia (2016) oleh Andi Muhammad Junus dan Andi Fatimah Junus yang diterbitkan Badan Penerbit Universitas Negeri Makassar di Makassar, dan Perkembangan Sejarah Sastra Indonesia (2017) oleh Rismawati yang diterbitkan Bina Karya Akademika di Banda Aceh.

Selanjutnya, menurut Rejo (2020) yang termasuk referensi hasil laporan penelitian adalah "Perkembangan Teater Kontemporer Indonesia" (2012) oleh Achmad Syaeful Anwar berupa disertasi yang dipertahankan di Fakultas Ilmu Pengetahuan Budaya Universitas Indonesia. Buku Kritik Sastra Indonesia Modern (2002) oleh Rachmat Djoko Pradopo merupakan hasil disertasinya yang berhasil dipertahankan di Fakultas Sastra Universitas Gadjah Mada Yogyakarta, serta buku Telaah Kritik Sastra Indonesia (1986) oleh Yudiono K.S. merupakan hasil tesisnya yang berhasil dipertahankan di program Ilmu Sastra Universitas Gadjah Mada Yogyakarta. Dari beberapa referensi yang dicetak dan didistribusikan secara umum, 
terdapat beberapa buku tersebut yang diubah dalam bentuk pdf digital dan dapat diunduh secara bebas di internet yakni buku Sejarah Sastra Indonesia (2011) oleh Rosida Rowati dan Ahmad Bahtiar yang diterbitkan Lembaga Penerbitan UIN Syarif Hidayatulloh, Sejarah Perkembangan Sastra Indonesia (2016) oleh Andi Muhammad Junus dan Andi Fatimah Junus yang diterbitkan Badan Penerbit Universitas Negeri Makassar, dan Perkembangan Sejarah Sastra Indonesia (2017) oleh Rismawati yang diterbitkan Bina Karya Akademika.

Capaian pembelajaran mata kuliah Sejarah Sastra ini adalah setelah mengikuti mata kuliah ini, mahasiswa mampu memahami dan menjelaskan konsep dasar penulisan sejarah sastra, problema penulisan sejarah sastra Indonesia, dan perkembangan sastra Indonesia dengan baik dan benar (Rejo, 2020). Hal ini sesuai dengan yang tertera dalam Rencana Pembelajaran Semester (RPS). Dengan demikian, ada tiga kompetensi yang akan didapatkan mahasiswa. Pertama, mahasiswa mampu memahami konsep dasar penulisan sejarah sastra. Kedua, mahasiswa mampu memahami problema penulisan sejarah sastra Indonesia. Ketiga, mahasiswa mampu memahami perkembangan sastra Indonesia. Berdasarkan capaian tersebut, maka deskripsi mata kuliah ini adalah membahas tentang konsep dasar penulisan sejarah sastra, problema penulisan sejarah sastra Indonesia, dan perkembangan sejarah sastra Indonesia (Rejo, 2020). Untuk perkembangan sejarah sastra Indonesia, akan dimulai dangan mengenalkan sejarah sastra periode Balai Pustaka, sejarah sastra periode Pujangga Baru, sejarah sastra Angkatan 45, sejarah sastra periode generasi Kisah dan Sastra, sejarah sastra periode generasi Horison, sejarah sastra periode sastra pemapanan, dan sejarah sastra periode sastra pembebasan. Masing-masing fase perkembangan tersebut akan dikelompokkan lagi berkait tentang bahan kajiannya, sehingga membentuk konstruksi pengetahuan sejarah sastra yang utuh, konstruktif, kronologis, komunikatif, dan mudah dipahami sebagai pengantar awal dalam memahami ilmu-ilmu sastra mutakhir selanjutnya.

\section{Problematika Pembelajaran dari Aspek Metode}

Ditinjau dari aspek metode, pembelajaran sejarah sastra di program studi ini akan terasa monoton jika didominasi dengan ceramah. Ceramah yang sering dan terlalu monoton tidak membentuk pengetahuan mahasiswa yang mandiri. Mahasiswa akan mengalami kecenderungan untuk selalu dicekoki terus menerus, sehingga mengakibatkan banyak mahasiswa yang hanya mengandalkan materi dari dosennya. Oleh karena itu, metode yang digunakan pengampu dalam hal ini harus memiliki inovasi, sehingga mahasiswa lebih akrab, senang, terbuka, dan percaya diri dalam berdiskusi berkait tentang ruang lingkup sejarah sastra, problema dalam penulisan sejarah sastra, serta perkembangan sejarah sastra Indonesia dari dulu sampai sekarang ini.

Dalam hal ini, peneliti sebagai pengampu mata kuliah menerapkan diskusi kelompok agar mahasiswa lebih mudah dalam memahami perkembangan sejarah sastra Indonesia. Diskusi kelompok tersebut disampaikan pada awal perkuliahan. Sebelum diskusi, mahasiswa diharuskan menyiapkan bahan diskusi, mulai dari makalah yang disusun dan silinda yang akan dipresentasikan. Kesemua itu harus dikumpulkan seminggu sebelum dipresentasikan. Dari makalah yang disusun, mahasiswa cenderung mengabaikan indikator-indikator topik materi yang disampaikan dalam kontrak perkuliahan. Hal ini mengakibatkan bahasan dalam makalah menjadi semakin luas, kurang terarah, dan tidak fokus. Indikator-indikator 
tersebut diberikan agar menjadi patokan mahasiswa dalam menyusun makalah tugasnya. Berkait dengan silinda yang mereka susun cenderung power text, artinya inti yang disampaikan dalam silinda tersebut belum tersampaikan. Selain itu, mahasiswa masih belum percaya diri dan presentasinya cenderung membaca untuk menegaskan, bukan menjelaskan yang telah disampaikan. Selain itu, dalam pelaksanaannya mahasiswa cenderung kurang kompak, masih terkesan individual. Kurang kerjasama, kekompakkan, saling membantu, saling mengejar dan menjatuhkan, itu yang terlihat dalam diskusi yang mereka lakukan. Dalam hal ini, peneliti cenderung mengatakan ini sebagai problematika. Oleh karena itu, koreksikoreksi yang demikian harus disampaikan ke mahasiswa agar mereka mengalami perubahan dari waktu ke waktu dan menjadi semakin lebih baik.

Tidak hanya diskusi kelompok yang bisa digunakan dalam pembelajaran ini, banyak metode yang dapat diterapkan bergantung konteks yang melingkupinya. Misalnya saja, pada era pandemik semacam ini, pembelajaran daring harus diterapkan. Itu juga harus disikapi dengan bijak, metode apa saja bisa diterapkan asalkan ditentukan terlebih dahulu bahan kajian dan indikator materi perkuliahan yang akan diberikan sehingga perkuliahannya bisa menjadi terarah, fokus, runtut, serta tidak merugikan satu sama lain. Yenni Hayati menawarkan inovasi perkuliahan Sejarah Sastra Indonesia dengan menggunakan metode diskusi kelompok model kepala bernomor. Menurut Yenni Hayati (2012), ada beberapa pembaharuan melalui metode yang ia lakukan ini. Pertama, praktis dan mudah dilaksanakan oleh setiap dosen karena alat bantunya mudah diperoleh dan diterapkan dalam kegiatan pembelajaran. Kedua, cukup efektif untuk menumbuhkembangkan kedisiplinan, minat, kerjasama, keaktifan, dan tanggung jawab mahasiswa karena metode inovasi ini menekankan kemampuan mahasiswa secara individual meskipun dilaksanakan secara berkelompok. Ketiga, cukup efektif untuk menumbuhkan budaya kompetitif di kalangan mahasiswa karena secara kejiwaan mahasiswa memiliki motivasi yang tinggi untuk tampil sebaik-baiknya secara individual dan memiliki keterlibatan emosional untuk menjaga solidaritas kelompok ketika menyampaikan hasil diskusi. Keempat, kegiatan perkuliahan benar-benar berpusat pada mahasiswa sehingga dapat menemukan jawaban sendiri (inkuiri) terhadap permasalahan yang didiskusikan. Dosen hanya sebatas menjadi fasilitator yang membantu mahasiswa dalam menumbuhkembangkan potensi dirinya (Hayati, 2012). Inovasi yang dilakukan Yenni Hayati tersebut merupakan salah satu inovasi yang bisa diimplementasikan. Selain itu, tidak menutup kemungkinan akan terdapat inovasiinovasi lain yang muncul, sehingga pembelajaran Sejarah Sastra tidak monoton dan menjadi lebih menarik minat perhatian mahasiswa khususnya yang menempuh pendidikan tinggi di wilayah perbatasan seperti ini.

\section{Problematika Pembelajaran dari Aspek Media}

Ditinjau dari aspek media, kecenderungan media yang digunakan dalam pembelajaran Sejarah Sastra di program studi Pendidikan Bahasa dan Sastra Indonesia ini adalah media silinda. Media ini dirasa sangat efektif dan efisien digunakan untuk menyampaikan materi perkuliahan. Selain silinda, media yang digunakan adalah papan tulis dan spidol. Untuk menambah penjelasan tambahan dari materi perkuliahan, papan tulis dan spidol merupakan pasangan serasi yang efektif dan efisien untuk digunakan. Alangkah lebih baik, jika ada spidol warna itu menjadikan materi yang diberikan bisa menjadi berwarna dan penuh dengan macam- 
macam kehidupan. Jika ada listrik mati maka penggunaan silinda menjadi tidak efektif, karena sebagai kampus perbatasan, kampus ini belum memiliki dan mempunyai alat khusus untuk menyimpan cadangan listrik atau sebagai sumber tenaga listrik. Dengan demikian, mau tidak mau penggunaan silinda yang awalnya efektif berubah menjadi tidak efektif. Oleh karena itu, ketergantungan dengan menggunakan media ini harus diperhatikan.

Tidak dipungkiri pula, penggunaan media ini memang memiliki beberapa keunggulan. Menurut Munadi (2008), ada beberapa keunggulan menggunakan media silinda. Pertama, mampu menampilkan objek-objek yang sebenarnya tidak ada secara fisik atau diistilahkan dengan imagery. Secara kognitif, pembelajaran dengan menggunakan mental imagery akan meningkatkan retensi mahasiswa dalam memahami materi perkuliahan. Kedua, mampu mengembangkan materi perkuliahan terutama berkait dengan membaca dan mendengarkan dengan mudah. Ketiga, memiliki kemampuan dalam menggabungkan semua unsur seperti teks, gambar, video, grafik, tabel, suara, dan animasi menjadi satu kesatuan penyajian yang terintegrasi. Keempat, dapat mengakomodasi mahasiswa sesuai dengan modalitas belajarnya terutama bagi mahasiswa yang memiliki tipe visual, auditif, kinestetik, atau yang lainnya.

Daryanto (2013) menambahkan keunggulan menggunakan media ini. Pertama, penyajiannya menarik karena ada permainan warna, huruf, animasi, baik animasi teks maupun animasi gambar atau foto. Kedua, lebih merangsang mahasiswa untuk mengetahui lebih jauh informasi pengetahuan tentang bahan ajar yang tersaji. Ketiga, pesan informasi pengetahuan secara visual mudah dipahami mahasiswa. Keempat, pengajar tidak perlu banyak menerangkan bahan ajar yang sedang disajikan. Kelima, dapat diperbanyak sesuai kebutuhan dan dapat digunakan secara berulang-ulang. Keenam, dapat disimpan dalam bentuk data optik atau magnetik seperti $C D$, disket, flasdisk, sehingga praktis untuk dibawa kemana-mana.

\section{Problematika Pembelajaran dari Aspek Mahasiswa}

Ditinjau dari aspek mahasiswa, problematika yang utama berkait dengan pembelajaran mata kuliah Sejarah Sastra ini adalah mahasiswa masih kurang disiplin, masih ada mahasiswa yang datang tidak tepat waktu saat perkuliahan dimulai. Hal ini masih dapat toleransi, karena disadari ada beberapa mahasiswa kampus ini yang bekerja yakni mencari tambahan biaya untuk melanjutkan perkuliahan di kampus ini dan untuk makan sehari-hari. Meskipun begitu, semangat belajar mereka harus dihargai dan diapresiasi.

Mahasiswa harus banyak mendapat motivasi yang kuat dan semangat dari dosen. Motivasi dan semangat merupakan hal vital yang tidak boleh dihilangkan. Dengan adanya motivasi dan semangat yang diberikan, harapannya mahasiswa menjadi semangat dan termotivasi untuk meningkatkan belajarnya di perguruan tinggi. Jangan sampai ada sesuatu hal, misalnya, dimarahi dosen, mahasiswa menjadi mogok untuk belajar. Tidak lulus mata kuliah melakukan demo secara liar. Cara-cara ortodoks semacam itu harus diubah. Oleh karena itu, sikap saling mengingatkan, saling memberitahu, saling berdiskusi, saling mencari solusi, tidak anarkis, merupakan tindakan bijak yang dapat diimplementasikan. Sehingga pembelajaran Sejarah Sastra di program studi ini menjadi pembelajaran yang menyenangkan, kreatif, inovatif, dan membuat mahasiswa menjadi ketagihan untuk belajar dan selalu belajar. Semangat belajar menjadi poin utama yang diterapkan. 
Menurut Mc. Donald (dalam Sardiman, 2012), motivasi belajar merupakan perubahan energi dalam diri seseorang yang ditandai dengan muncul-nya feeling dan ditandai dengan tanggapan terhadap tujuan. Sardiman menambahkan dengan motivasi dapat menggerakkan mahasiswa untuk melakukan sesuatu atau ingin melakukan sesuatu. Dessler (1997) menyebut motivasi sebagai hal sederhana, karena orang-orang pada dasarnya termotivasi atau terdorong untuk berperilaku dalam cara tertentu yang dirasakan mengarah pada perolehan ganjaran (at deserts acquirement), sedangkan As'ad (2003) menyebut motivasi dengan istilah dorongan, yakni dorongan atau tenaga sebagai gerak jiwa atau jasmani untuk berbuat sehingga motif melakukan tersebut merupakan suatu driving force yang menggerakkan manusia untuk bertingkah laku dan di dalam perbuatannya itu mempunyai tujuan tertentu. Berdasarkan pandangan beberapa pakar tersebut, dapat disimpulkan bahwa motivasi merupakan hal vital untuk dijadikan sebagai alat agar mahasiswa di kampus perbatasan ini menjadi semangat belajar. Dengan motivasi yang dilakukan secara intrinsik maupun ekstrinsik, dari dalam maupun dari luar, membuat mahasiswa dapat mencapai tujuan yang ingin dicapainya.

Menurut Santrock (2007), ada dua aspek yang membangun motivasi belajar mahasiswa. Pertama, motivasi ekstrinsik, yakni melakukan sesuatu untuk mendapatkan sesuatu yang lain cara untuk mencapai tujuan. Motivasi ekstrinsik sering dipengaruhi oleh insentif eksternal seperti imbalan dan hukuman. Kedua, motivasi intrinsik, yakni motivasi internal untuk melakukan sesuatu demi sesuatu itu sendiri (tujuan itu sendiri). Ada dua jenis motivasi intrinsik. Pertama, motivasi intrinsik yang berdasarkan determinasi diri dan pilihan personal. Dalam pandangan ini, mahasiswa ingin percaya bahwa mereka melakukan sesuatu karena kemauan sendiri, bukan karena kesuksesan atau imbalan eksternal. Minat intrinsik mahasiswa akan meningkat jika mereka mempunyai pilihan dan peluang untuk mengambil tanggung jawab personal atas pembelajaran mereka. Kedua, motivasi intrinsik berdasarkan pengalaman optimal. Pengalaman optimal kebanyakan terjadi ketika orang merasa mampu dan berkonsentrasi penuh saat melakukan suatu aktivitas serta terlibat dalam tantangan yang mereka anggap tidak terlalu sulit tetapi juga tidak terlalu mudah.

Selanjutnya, menurut French (dalam Syaodih S., 2003) mahasiswa yang termotivasi oleh prestasi akan bertahan lebih lama pada tugas dibandingkan dengan mahasiswa yang kurang tinggi dalam motivasi berprestasi, kendati mereka mengalami kegagalan. Mereka akan menghubungkan kegagalan mereka dengan kurangnya usaha, bukannya dengan faktor-faktor eksternal seperti kesukaran tugas, keberuntungan, dan sebagainya. Mahasiswa yang termotivasi berprestasi menginginkan keberhasilan, dan ketika mereka gagal akan melipatgandakan usaha mereka sehingga dapat berhasil.

Mc Clelland (dalam Wahidin, 2001) mengungkapkan ciri-ciri seseorang memiliki motivasi berprestasi tinggi. Pertama, mempunyai keinginan untuk bersaing secara sehat dengan dirinya sendiri maupun orang lain. Kedua, mempunyai keinginan bekerja dengan baik. Ketiga, berfikir solutif dengan memahami keunggulan dan kelemahan dirinya. Keempat, memiliki tanggung jawab pribadi. Kelima, mampu membuat terobosan dalam berfikir. Keenam, berfikir strategis dalam jangka panjang. Ketujuh, selalu memanfaatkan umpan balik untuk perbaikan.

Heckhausen (dalam Monks, Knoers, \& Haditono, 2002), mengklasifikasikan standar keunggulan motivasi berprestasi menjadi tiga. Pertama, standar keunggulan 
dalam penyelesaian tugas. Kedua, perbandingan dengan prestasi sebelumnya. Ketiga, perbandingan dengan prestasi orang lain. Dalam suatu kompetisi, orang yang mempunyai motivasi berprestasi tinggi akan selalu mengejar yang terbaik di antara rival-rivalnya. Dengan demikian, dapat disimpulkan bahwa seseorang yang memiliki motivasi berprestasi akan memiliki kelebihan untuk menjadikan dirinya berhasil dan sukses dalam berbagai kegiatan dalam kehidupan ini, termasuk didalamnya adalah keberhasilan dalam prestasi belajarnya. Oleh karena, peran motivasi dan semangat menjadi dua hal yang tidak bisa dihilangkan. Keduanya harus menjadi suplemen untuk mahasiswa yang berada di wilayah perbatasan agar meningkatkan prestasi belajarnya, sehingga dapat berguna pada perkembangan kehidupannya yang akan datang sekaligus dapat menjadi kebiasaan positif untuk diterapkan kedepannya.

\section{Problematika Pembelajaran dari Aspek Literasi}

Ditinjau dari aspek literasi, ada beberapa problematika yang dihadapi dalam pembelajaran Sejarah Sastra di program studi yang berada di kawasan perbatasan ini. Pertama, tingkat ketrampilan membaca dan menulis mahasiswa masih rendah. Budaya membaca dan menulis perlu dibangkitkan lagi dalam hal ini, terutama untuk mahasiswa yang memprogram mata kuliah ini. Memang wilayah ini jauh dari toko yang menjual buku-buku untuk perguruan tinggi, tetapi mahasiswa dapat memanfaatkan teknologi digital untuk mendapatkan ebook-ebook yang dibutuhkan. Selain itu, mungkin di setiap pojok kelas disediakan buku-buku bacaan perkuliahan, buku fiksi, atau buku nonfiksi, majalah-majalah pendidikan, agar mahasiswa semakin gemar membaca. Mading-mading kampus dihidupkan kembali dengan menyediakan rubrik-rubrik kekinian, sehingga mahasiswa tidak ketinggalan informasi yang kekinian. Buku-buku bacaan berkait ilmu sastra (sejarah sastra, teori sastra, kritik sastra, baik ilmu sastra interdisipliner, multidisipliner, monodisipliner, atau transdisipliner) dan karya sastra harus diperbanyak lagi, agar tidak ada mahasiswa yang tidak mengetahui perkembangan sastra terbaru. Poster tentang tokoh-tokoh sastrawan besar Indonesia dan karya emasnya wajib dijadikan pajangan pada setiap sudut ruang program studinya. Hal ini bertujuan agar tokoh-tokoh besar tersebut bisa menjadi cerminan teladan yang bisa diteladani mahasiswa-mahasiswa ini. Selain itu, petikan-petikan kalimat inspiratif wajib ada untuk memberi semangat mahasiswa yang menempuh pendidikan di kampus wilayah perbatasan NKRIRDTL ini.

Tugas-tugas yang mengharuskan membaca dan menulis harus selalu ditingkatkan dari waktu ke waktu. Ketrampilan membaca dan menulis mahasiswa harus banyak dilatih. Semangat dan motivasi harus selalu diberikan ke mahasiswa. Pentingnya membaca dan menulis harus disampaikan ke mahasiswa, baik secara tersirat ataupun tersurat. Mahasiswa di kawasan perbatasan khususnya harus banyak-banyak diarahkan, agar tidak tersesat ke jalan yang salah. Itu semua kewajiban mendidik mahasiswa, tetapi jika dijalankan dengan penuh tanggung jawab akan mendapatkan hasil yang baik di kemudian hari. Kedua, koleksi bacaan berkait Sejarah Sastra di perpustakaan harus ditingkatkan terutama untuk buku-buku yang terbit tahun 2000-an. Berbagai lomba atau kegiatan berkait literasi semacam ini harus sering diadakan. Koleksi buku-buku karya sastra kekinian harus diadakan pula, karena di wilayah ini tidak ada toko buku. Jika memungkinkan disediakan ruang baca digital yang berisi koleksi-koleksi digital kekinian milik perpustakaan. Ketiga, ada sebagian mahasiswa yang belum memiliki ponsel dan mahir dalam 
pengoperasian komputer. Ini menjadi problematika yang besar. Pada era revolusi 4.0 masih ada mahasiswa yang belum memiliki ponsel. Jika belum mahir mengoperasikan komputer, ini masih bisa dipelajari lebih lanjut, tetapi jika tidak memiliki ponsel ini harus diperhatikan lagi. Sebagai dosen pengampu, peneliti menghimbau mahasiswa untuk menabung agar bisa memiliki ponsel. Peneliti menginspirasi dan memberi semangat agar bisa mengajukan beasiswa yang jika lolos bisa digunakan untuk membeli ponsel. Ponsel tidak hanya sebagai alat komunikasi, tetapi keberadaannya sekarang telah menjadi sumber belajar atau sumber kehidupan bagi mahasiswa apalagi di era revolusi industri 4.0 .

\section{PENUTUP}

Berdasarkan uraian di depan, dapat disimpulkan bahwa terdapat beberapa problematika yang dialami dalam pembelajaran mata kuliah Sejarah Sastra pada program studi Pendidikan Bahasa dan Sastra Indonesia di kampus wilayah perbatasan NKRI-RDTL di antaranya problematika dari aspek materi atau bahan ajar, metode, media, mahasiswa, dan literasi. Lima aspek tersebut memiliki kelemahan dan problematika masing-masing yang harus dicarikan solusi penyelesaiannya sebagai bahan evaluasi. Melalui solusi tersebut, akan dihasilkan beberapa varian rasa yang bisa dinikmati dalam pembelajaran mata kuliah Sejarah Sastra berikutnya. Hal ini menjadi penting, mengingat setiap kegiatan yang dilakukan harus memberi kontribusi positif pada mahasiswa. Sehingga kegiatankegiatan evaluatif semacam ini harus dilakukan.

Memasuki era revolusi 4.0 semacam ini tidak bisa dipungkiri telah membawa dampak perubahan yang besar pada setiap tatanan kehidupan. Hal ini bukanlah sebagai musibah kehidupan, tetapi sebuah tantangan yang harus dihadapi agar sebagai manusia yang hidup di dunia ini tidak termakan oleh arus zaman yang mengalami perkembangan semakin pesat seperti saat ini. Jika pembelajaran konvensional atau tradisional sudah tidak relevan diterapkan, berarti mau tidak mau, siap tidak siap, konsep pembelajaran harus ikut mengalami perubahan. Untuk menghadapi itu, maka strategi dan upaya yang dilakukan pengampu mata kuliah harus condong dan berfokus pada konsep dan metode pembelajaran kekinian. Dengan demikian, pembelajaran Sejarah Sastra tidak monoton, semakin modern, kekinian, dan tidak menjadi pembelajaran yang membosankan. Hal ini yang menjadi target ke depannya. Apapun era yang mengikuti, pembelajaran Sejarah Sastra masih tetap kontekstual dengan perubahan perkembangan zaman tersebut, tidak jadul, tetap berisi, serta semakin modern dan kekinian.

\section{DAFTAR PUSTAKA}

As'ad, M. (2003). Psikologi Industri. Yogyakarta: Liberty.

Daryanto. (2013). Media Pembelajaran: Peranannya Sangat Penting dalam Mencapai Tujuan Pembelajaran. Yogyakarta: Gava Media.

Dessler, G. (1997). Manajemen Personalia. Jakarta: Erlangga.

Hayati, Y. (2012). Inovasi Perkuliahan Sejarah Sastra Indonesia dengan Menggunakan Metode Diskusi Kelompok Model Kepala Bernomor. Komposisi: Jurnal Pendidikan Bahasa, Sastra, dan Seni, 11(1). http://ejournal.unp.ac.id/index.php/komposisi/article/view/76

Monks, F. J., Knoers, A. M. P., \& Haditono, S. R. (2002). Psikologi Perkembangan. 
Pengantar Dalam Berbagai Perkembangannya. Yogyakarta: Gadjah Mada Univesity Press.

Munadi, Y. (2008). Media Pembelajaran: Sebuah Pendekatan Baru. Jakarta: Gaung Persada Press.

Rejo, U. (2020). Bahan Ajar Mata Kuliah Sejarah Sastra. Bahan ajar tidak diterbitkan. Kefamenanu: Program Studi Pendidikan Bahasa dan Sastra Indonesia Fakultas Ilmu Pendidikan Universitas Timor.

Riana, K. (2016). Sejarah Terjadinya Republik Demokratik Timor Leste dan Bahasanya: Sekilas Lintas. Dalam I. K. Sudewa \& I W. Teguh (Ed.), Prosiding Seminar Nasional Bahasa, Politik, dan Kekuasaan dalam Dinamika Kebudayaan. Denpasar: FIB Universitas Udayana. https://simdos.unud.ac.id/uploads/file_penelitian_1_dir/5be8d5be0e93617e6 d5628c782ebb6d6.pdf

Santrock, J. W. (2007). Psikologi Pendidikan. Jakarta: Kencana.

Sardiman, A. M. (2012). Interaksi dan Motivasi Belajar Mengajar. Jakarta: Rajawali Press.

Syaodih S., N. (2003). Landasan Psikologi Proses Pendidikan. Bandung: Remaja Rosdakarya.

The Partnership for Governance Reform. (2011). "Kebijakan Pengelolaan Kawasan Perbatasan Indonesia". Paper tidak diterbitkan.

Wahidin. (2001). Hubungan antara Kecerdasan Emosional dan Motivasi Berprestasi dengan Prestasi Belajar. Tesis. Universitas Gadjah Mada.

Wahono, Niswatul, I., \& Setiawan, A. (2020). Andragogi: Paradigma Pembelajaran Orang Dewasa pada Era Literasi Digital. Dalam Y. Wulandari \& V. R. Fitriyani (Eds.) Proceding Literasi dalam Pendidikan di Era Digital Untuk Generasi Milenial. Surabaya: Universitas Muhamadiyah Surabaya. http://repository.umsurabaya.ac.id/5225/3/4.ANDRAGOGI_PARADIGMA_PEMBELAJARA N_(1).pdf 